\title{
Metabolite correlation with antioxidant activity in different fruit maturation stages of Physalis peruviana
}

\author{
SYARIFUL MUBAROK ${ }^{1,2, \vartheta}$, FIKY YULIANTO WICAKSONO ${ }^{1,2}$, RAHMAT BUDIARTO ${ }^{1}$, \\ BAYU PRADANA NUR RAHMAT ${ }^{2}$, SUCINTA AULIDA KHOERUNNISA ${ }^{1}$ \\ ${ }^{1}$ Department of Agronomy, Faculty of Agriculture, Universitas Padjadjaran. J1. Raya Bandung-Sumedang Km. 21, Jatinangor, Sumedang 45363, West \\ Java, Indonesia. Tel./fax. +62-22-7796320, `email: syariful.mubarok@unpad.ac.id \\ ${ }^{2}$ Vocation Program of Agrotechnopreneur, Universitas Padjadjaran. J1. Raya Bandung-Sumedang Km. 21, Jatinangor, Sumedang 45363, West Java, \\ Indonesia
}

Manuscript received: 18 March 2021. Revision accepted: 21 April 2021.

\begin{abstract}
Mubarok S, Wicaksono FY, Budiarto R, Rahmat BPN, Khoerunnisa SA. 2021. Metabolite correlation with antioxidant activity in different fruit maturation stages of Physalis peruviana. Biodiversitas 22: 2743-2749. Fruit development influences the metabolites contents and then its biological activity, however, such report is still limited in goldenberry (Physalis peruviana L.). This work aimed to evaluate metabolite variability and its correlation to antioxidant activity in several stages of fruit maturation in goldenberry originating from Sumedang, Indonesia. The research was laid out in a completely randomized design with six different treatments in term of fruit maturation stages. Only fresh and pest-disease-free fruits collected from local farm were prepared for several metabolites assay, i.e $\mathrm{pH}$, total soluble solid (TSS), lycopene, $\beta$-carotene, polyphenol, flavonoid and its antioxidant activity. The statistical analysis resulted in a significant improvement of all fruit metabolite variables in response to fruit maturation process, except polyphenol. Compared to the oldest fruit stage of S6 (orange berry covered by full wilt white calyx), the youngest fruit of S1 (green berry covered by fresh green calyx) increased the $\mathrm{pH}$, TSS, lycopene, $\beta$-carotene and flavonoid by about $7 \%, 67.5 \%$, eight-fold, nine-fold and two-fold, respectively. Pearson correlation analysis showed a significant and positive correlation between all metabolite variables (except polyphenol) to antioxidant activity of goldenberry fruit.
\end{abstract}

Keywords: $\beta$-carotene, flavonoid, goldenberry, lycopene, polyphenol, TSS

\section{INTRODUCTION}

Goldenberry (Physalis peruviana L.) is an exotic perennial tropical shrub native to South America, specifically Peruvian Andes as the center of origin (Legge 1974). Goldenberry has a wide growing location in numerous countries worldwide, leading to ecotypes phenomenon as indicated by various fruit size, color, taste, and plant size in each specific location (Puente et al. 2011). Goldenberry is classified into husk tomato as the most diverse and important genera in Solanaceae family (Sadiyah et al. 2021).

The rapid interest to grow goldenberry is associated with its low-calorie but high-nutritious content (Mayorga et al. 2001; Joshi and Joshi 2015; Yildiz et al. 2015). Goldenberry can be consumed in raw form of salad or served as processed products, such as candy, cake, jam, juice, raisin, pomace and other desserts (Ramadan and Moersel 2007; Ramadan and Moersel 2009; Sharoba and Ramadan 2011). Numerous pharmacological properties of goldenberry are analgesic, antispasmodic, antiseptic, antimicrobial and sedative (Januário et al. 2000; Puente et al. 2011). These pharmacological characters associated with metabolite content and composition.

In case of fruit, metabolites content could be influenced by its maturation stages. As the fruit getting mature, there are several alterations in terms of chemical, physical (e.g. color) and biological properties (Gil et al. 1995; Trinchero et al. 1999; Ramadan and Morsel 2003; Serrano et al. 2005; Ersoy 2011). Fruit maturation process allowed the occurrence of metabolite degradation processes leading to the alteration of the nutritional value, thus the evaluation of metabolites in relation to fruit ripening stage becomes an interesting issue (Etzbach et al. 2018).

One of important pharmacological properties of natural products of fruit was antioxidant activity. Among 97 plants collected from Gunung Gede Pangrango national park in West Java, the highest antioxidant activity and the most potential cervix anticancer plants were goldenberry (Arbiastutie et al. 2017). Numerous studies on antioxidant activity and metabolite variation related to fruit ripening have been conducted in mangoes (Islam et al. 2013), God's crown (Soeksmanto et al. 2007), goldenberry (Bravo et al. 2015). Correlation analysis previously reported to display the relationship among morphological characters (Budiarto et al. 2021); among pigmentation content such as chlorophyll- $\alpha$, chlorophyll- $\beta$, and carotene (Yora et al. 2018), and physical characters of goldenberry fruit (Yildiz et al. 2015), opening the possibility to use this approach to reveal the metabolites and antioxidant relationship. Because of the major influence of phenotype (genotype and growing location) on metabolite content (Khodadadi et al. 2015; Yusnawan 2016; Calvindi et al. 2020), further study specifically for goldenberry from Indonesia was needed. Therefore, this study aimed to evaluate metabolite variability and its correlation to antioxidant activity in 
several stages of fruit maturation in goldenberry originating from Sumedang, Indonesia.

\section{MATERIALS AND METHODS}

\section{Preparation of plant materials}

Goldenberry fruits were harvested from Waida Farm Sumedang (-6.87359; 107.82360; 946 meters above sea levels), in the morning using hand picking technique. Only selected goldenberry fruits with fresh and pest-disease-free conditions used in present work. This work was arranged in a completely randomized design, with 6 different maturation stages in term of fruit maturation stages, i.e stage 1 (unripe green berry covered by green calyx), stage 2 (yellow berry covered by whitish-green calyx), stage 3 (yellow berry covered by greenish-yellow calyx), stage 4 (yellow berry covered by yellowish-white calyx), stage 5 (yellow berry covered by semi wilting yellowish-white calyx), stage 6 (yellow berry covered by wilting white calyx) (Figure 1). Each treatment consisted of four replications, so that there were 24 experimental units involved, with 20 goldenberry fruits for each experimental unit. Each sample was measured in triplicate

\section{Analysis of pH and total soluble solids (TSS)}

Goldenberry fruits with a fresh weight of around $5 \mathrm{~g}$ were ground to collect the fruit juice for $\mathrm{pH}$ analysis by using a pH meter. For TSS analysis, the $5 \mathrm{~mL}$ fruit juice was prepared in microtube. The microtube was then centrifugated at $1000 \mathrm{rpm}$. The $1000 \mu \mathrm{L}$ supernatant was then collected using a micropipette and transferred to refractometer.

\section{Analysis of antioxidant activity (DPPH free radical scavenger)}

The $20 \mathrm{mg}$ of dried sample of goldenberry in a dark bottle was added with $2 \mathrm{~mL}$ methanol and then homogenized. The $0.6 \mathrm{~mL}$ supernatant was then transferred to a test tube. The 2,2-diphenyl-1-picryl-hydrazyl-hydrate (DPPH) solution was prepared by combining $0.8 \mathrm{mg}$ DPPH with $20 \mathrm{~mL}$ methanol inside an Erlenmeyer flask covered by an aluminum foil to prevent oxidation. The $2.5 \mathrm{~mL}$ DPPH solution was added into the test tube containing the supernatant sample and incubated for $15 \mathrm{~min}$ prior to the measurement by using UV-Vis spectrophotometer.

\section{Analysis of lycopene and $\beta$-carotene}

Analysis of lycopene and $\beta$-carotene was followed previous study by Mubarok et al. (2015). $1 \mathrm{~g}$ fresh goldenberry fruit sample was ground prior to transfer to dark bottle for preventing any light penetration. $-7 \mathrm{~mL}$ acetone-hexane- previously prepared from acetone and hexane with a ratio 4:6 - was transferred into dark bottle of sample and then homogenized. After 10 minutes, there were two separated layers formed, i.e supernatant and debris. The supernatant was transferred into a new bottle and then measured its absorbance by using UV-Vis spectrophotometer at various wavelengths; $663 \mathrm{~nm}$ (A663), $645 \mathrm{~nm}$ (A645), $505 \mathrm{~nm}$ (A505), and $453 \mathrm{~nm}$ (A453). The content of lycopene (CLYL) and $\beta$-carotene (CCAR) was then measured using the following formula:

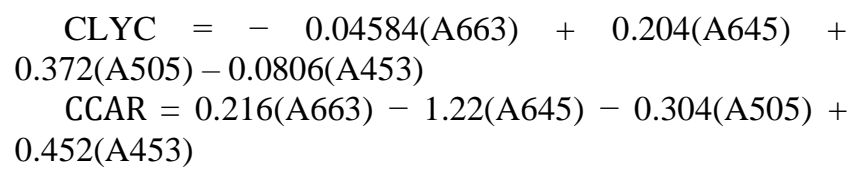

The results of lycopene and $\beta$-carotene content were then expressed in $\mu \mathrm{g} \mathrm{g}^{-1}$ of fresh weight (FW).

\section{Analysis of polyphenol}

0.3 grams of dried goldenberry sample in the microtube was added with $1 \mathrm{~mL}$ methanol and then centrifugated at $6000 \mathrm{rpm}$ for 5 minutes. The $50 \mu \mathrm{l}$ of supernatant was transferred into a test tube and added with $2 \mathrm{~mL}$ of $7,5 \%$ $\mathrm{Na}_{2} \mathrm{CO}_{3}$ prior to incubation at $45^{\circ} \mathrm{C}$ for 15 minutes. The absorbance was measured using UV-Vis spectrophotometer at $765 \mathrm{~nm}$. The result was plotted into a standard curve and then used for calculation of polyphenol content $\left(\mu \mathrm{g} \mathrm{g}^{-1}\right.$ FW).
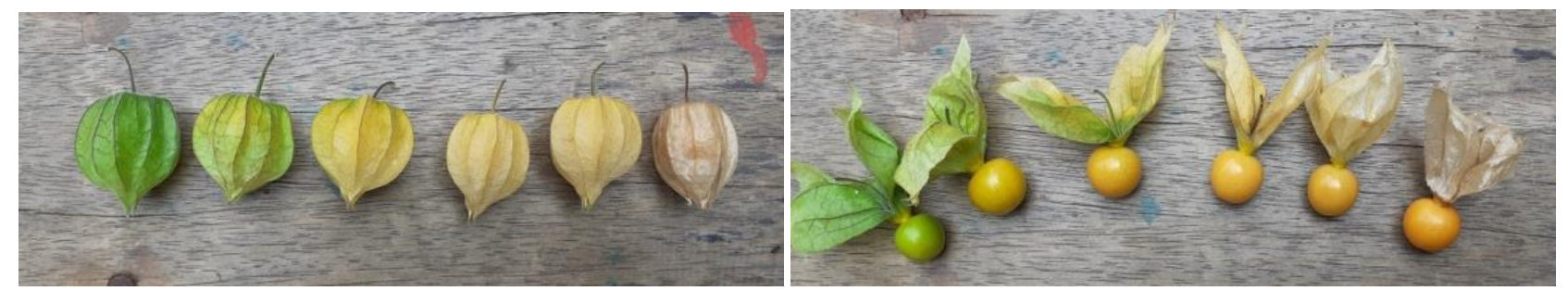

Figure 1. Various Physalis peruviana L. fruit maturation stages (from left to right), i.e. stage 1 (green berry covered by fresh green calyx), stage 2 (greenish-yellow berry covered by fresh pale green calyx), stage 3 (pale yellow berry covered by fresh greenish-yellow calyx), stage 4 (pale yellow berry covered by fresh pale yellow calyx), stage 5 (yellow berry covered by semi wilt pale yellow calyx), stage 6 (orange berry covered by full wilt white calyx), (unripe green berry covered by green calyx), stage 2 (greenish-yellow berry covered by whitish-green calyx), stage 3 (pale yellow berry covered by greenish-yellow calyx), stage 4 (pale yellow berry covered by yellowish-white calyx), stage 5 (yellow berry covered by semi wilting-yellowish white calyx), stage 6 (yellow berry covered by wilting white calyx) 


\section{Analysis of flavonoid}

Analysis of flavonoid on dried goldenberry sample followed the $\mathrm{AlCl}_{3}$ method. 0.5 grams of dried sample in the $25 \mathrm{~mL}$ volumetric flask was added with $10 \mathrm{~mL}$ ethanol and then homogenized by using a sonicator bath for 5 minutes. The $4 \mathrm{~mL}$ clear homogenized solution that had been separated from its sediment was placed in microtube prior to centrifuge at $6000 \mathrm{rpm}$ for 5 minutes. Two $\mathrm{mL}$ supernatant was then put into a test tube and added with 2 $\mathrm{mL}$ of $2 \% \mathrm{AlCl}_{3}$ that dissolved in ethanol and then rehomogenized by using vortex. The sample was then incubated at $45^{\circ} \mathrm{C}$ for 30 minutes. The measurement of absorbance by using UV-Vis spectrophotometer was done at $415 \mathrm{~nm}$. The result was plotted into a standard curve and used to calculate flavonoid content $\left(\mu \mathrm{g} \mathrm{g}^{-1} \mathrm{FW}\right)$.

\section{Analysis of data}

Analysis of variance (ANOVA) and Pearson correlation analysis was performed by using Statistical Tool for Agricultural Research (STAR) version 2.0.1. For any significant differences between treatments, the Duncan Multiple Range Test (DMRT) was further evaluated at level of confident of $5 \%$.

\section{RESULTS AND DISCUSSION}

\section{Fruit juice pH and TSS}

The result showed that goldenberry fruit juice $\mathrm{pH}$ level was significantly influenced by the fruit maturation stages (Figure 2). The pattern was the older the stages, the increase the $\mathrm{pH}$ level. The lowest $\mathrm{pH}$ was found in the stage of green berry covered by fresh green calyx (S1), whereas the highest result was measured in fruit from the stage of orange berry covered by full wilt white calyx. The increase of $\mathrm{pH}$ in $\mathrm{S} 1$ compared to $\mathrm{S} 6$ was caused by the loss of acidic compounds due to hydrolysis that continuously happened during the fruit ripening process. In addition, some fruit organic acid was apparently converted into monosaccharides such as glucose and fructose during the fruit ripening process (Mahmood et al. 2012). This finding was in agreement with previous studies in pomegranate (Zarei et al. 2011; Ben-Arie et al. 1984), tomato (Monerruzzaman et al. 2008), and goldenberry (Puente et al. 2011; Salazar et al. 2008).

Fruit maturity stages also affected fruit juice TSS level significantly. The TSS is a simple and feasible variable of refractometric index that showed the proportion of dissolved solids in a solution and expressed in \% units. In terms of fruit juice, most of dissolved solid were sugars, including sucrose and hexose (Beckles 2012). The highest TSS was measured in S5 (yellow berry covered by semi wilt pale yellow calyx) that was no significant different than S6 (orange berry covered by full wilt white calyx). At the same time, the lowest result was observed in S1 (green berry covered by fresh green calyx) (Figure 3 ). The rate of TSS improvement in S6 was $67.5 \%$ compared to S1. The breaking down of starch and polysaccharide from the cell wall to be monosaccharide (glucose, fructose, sucrose) that happened during the ripening process was the main cause of higher TSS content on ripened fruit (Crouch 2003; Balaguera-Lopez et al. 2015). In similar to our finding, previous study by Gutierrez et al. (2008) also showed the increasing pattern of TSS during goldenberry ripening.

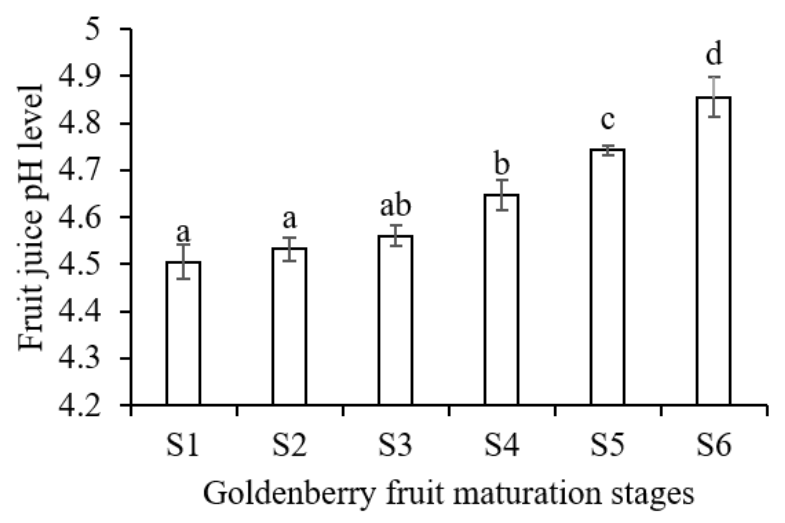

Figure 2. Effect of six different goldenberry maturation stages S1 (green berry covered by fresh green calyx), S2 (greenishyellow berry covered by fresh pale green calyx), S3 (pale yellow berry covered by fresh greenish-yellow calyx), S4 (pale yellow berry covered by fresh pale yellow calyx), S5 (yellow berry covered by semi wilt pale yellow calyx), S6 (orange berry covered by full wilt white calyx) - on fruit juice $\mathrm{pH}$ level. Note: the different alphabet above the rectangular bar is significantly different based on DMRT at $\alpha 5 \%$; the error bar represents the standard deviation.

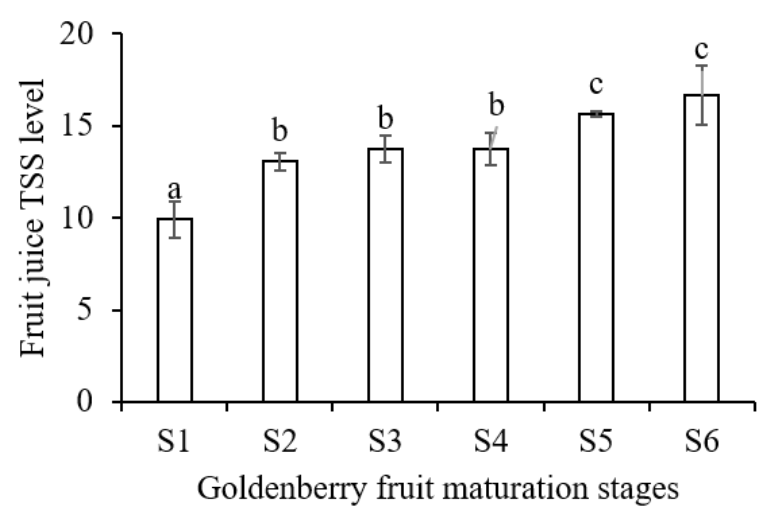

Figure 3. Effect of six different goldenberry maturation stages S1 (green berry covered by fresh green calyx), S2 (greenishyellow berry covered by fresh pale green calyx), S3 (pale yellow berry covered by fresh greenish-yellow calyx), S4 (pale yellow berry covered by fresh pale yellow calyx), S5 (yellow berry covered by semi wilt pale yellow calyx), S6 (orange berry covered by full wilt white calyx) - on fruit juice TSS $\left({ }^{0}\right.$ Brix). Note: the different alphabet above the rectangular bar is significantly different based on DMRT at $\alpha 5 \%$; the error bar represents the standard deviation. 


\section{Lycopene and $\beta$-carotene}

Both $\beta$-carotene and lycopene are carotenoids that have already well-known for their antioxidant properties (Başkan et al. 2013; Suwanaruang 2016; Burri 1997). The result from statistical analysis revealed that both lycopene and $\beta$-carotene content of goldenberry fruits continuously increased during the ripening process. The younger fruit, the lower content of lycopene (Figure $4 a$ ) and $\beta$-carotene (Figure 4b). The S6 fruit, as the oldest fruit stage, had the highest lycopene and $\beta$-carotene content for more than eight-fold and nine-fold greater than S1 fruit as the youngest one (Figure 4). Earlier works by Etzbach et al. 2018 and Hdider et al. (2013) showed similar results. The transformation of chlorophyll into chromoplast due to the deposition of lycopene and $\beta$-carotene caused the changes in fruit color from green into yellow-red (Mubarok et al. 2015). In addition to ripening stages (Ilahy et al. 2011), the content of carotenoids was possibly determined by plant genetic factors (Ordonez-Santos and Ledezma-Realpe 2013; Davies 2000).

\section{Polyphenol and flavonoid}

This work revealed that polyphenol content of goldenberry was not significantly affected by the fruit maturation stages (Figure 5.A). The polyphenol in present work varied from $0.01356-0.01361 \mu \mathrm{g} \mathrm{g}^{-1} \mathrm{FW}$. A previous study reported that the polyphenol increased as the fruit getting mature (Butkhup and Samappito 2011), however numerous other studies reported the opposite result (Fawole and Opara 2013; Fredes et al. 2012). The polyphenol content in fruit was associated with the activity of polyphenol oxidase (PPO), where the increase of PPO caused the decline of polyphenol in the ripe fruit (OrtegaGarcia et al. 2008).

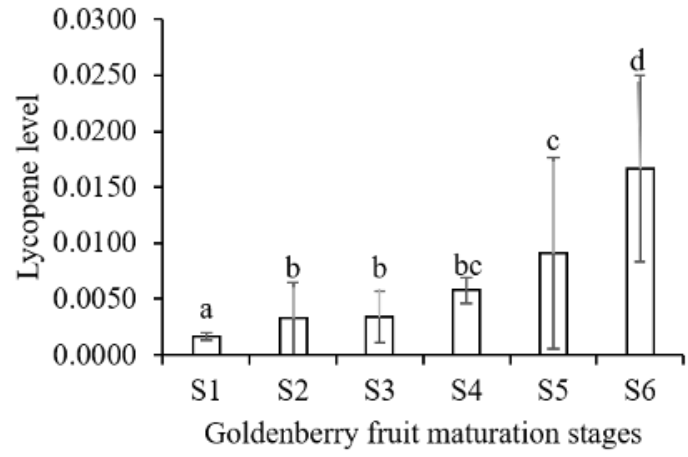

A

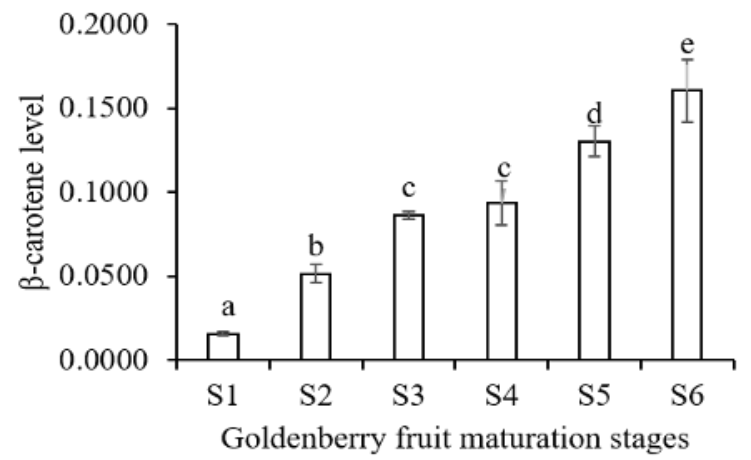

B

Figure 4. Effect of six different goldenberry maturation stages - S1 (green berry covered by fresh green calyx), S2 (greenish-yellow berry covered by fresh pale green calyx), S3 (pale yellow berry covered by fresh greenish-yellow calyx), S4 (pale yellow berry covered by fresh pale yellow calyx), S5 (yellow berry covered by semi wilt pale yellow calyx), S6 (orange berry covered by full wilt white calyx) - on (A) lycopene level $\left(\mu \mathrm{g} \mathrm{g}^{-1} \mathrm{FW}\right)$ and (B) $\beta$-carotene level $\left(\mu \mathrm{g} \mathrm{g}^{-1} \mathrm{FW}\right)$. Note: the different alphabet above the rectangular bar is significantly different based on DMRT at $\alpha 5 \%$; the error bar represents the standard deviation.

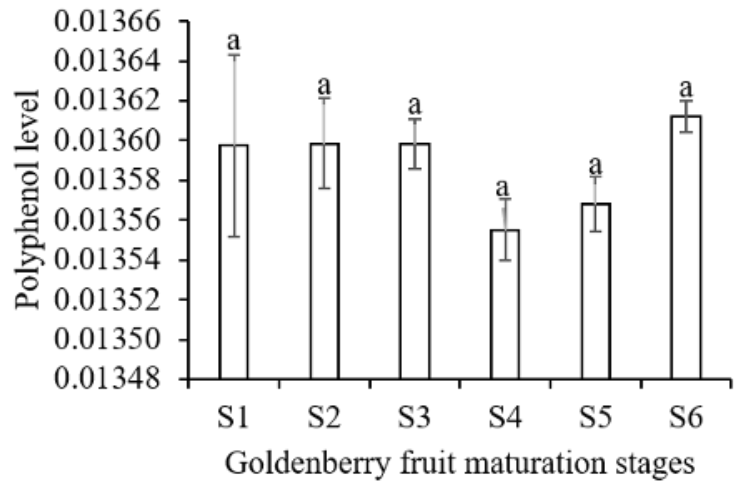

A

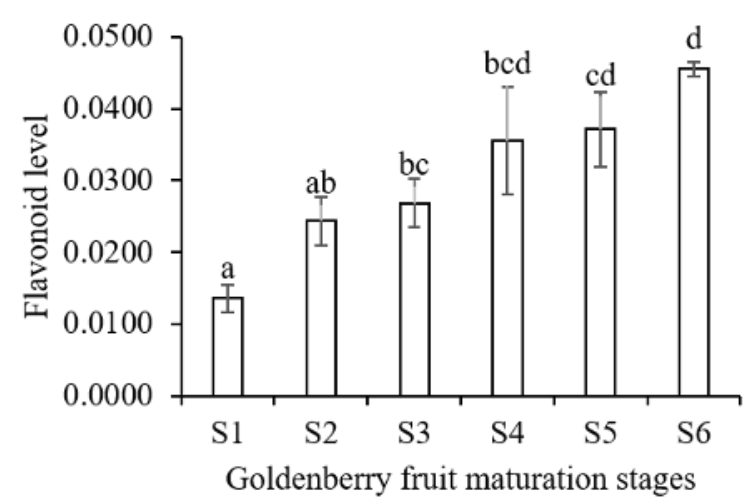

B

Figure 5. Effect of six different goldenberry maturation stages - S1 (green berry covered by fresh green calyx), S2 (greenish-yellow berry covered by fresh pale green calyx), S3 (pale yellow berry covered by fresh greenish-yellow calyx), S4 (pale yellow berry covered by fresh pale yellow calyx), S5 (yellow berry covered by semi wilt pale yellow calyx), S6 (orange berry covered by full wilt white calyx) - on (A) polyphenol level $\left(\mu \mathrm{g} \mathrm{g}^{-1} \mathrm{FW}\right)$ and (B) flavonoid level $\left(\mu \mathrm{g} \mathrm{g}^{-1} \mathrm{FW}\right)$. Note: the different alphabet above the rectangular bar is significantly different based on DMRT at $\alpha 5 \%$; the error bar represents the standard deviation 
Table 1. Pearson correlation coefficient among fruit juice $\mathrm{pH}$ TSS, antioxidant activity, lycopene, $\beta$-carotene, polyphenol and flavonoid level in six different goldenberry fruit maturation stages

\begin{tabular}{lllllll}
\hline Variable & pH & TS & AT & LC & CR & PP \\
\hline TS & $0.8076^{*}$ & & & & & \\
AT & $0.8528^{*}$ & $0.8636^{*}$ & & & & \\
LC & $0.7227^{*}$ & $0.6262^{*}$ & $0.6882^{*}$ & & & \\
CR & $0.9082^{*}$ & $0.866^{*}$ & $0.9709^{*}$ & $0.7188^{*}$ & & \\
PP & -0.0611 & 0.0551 & 0.0048 & 0.0614 & -0.0507 & \\
FL & $0.8435^{*}$ & $0.8499^{*}$ & $0.8818^{*}$ & $0.6907^{*}$ & $0.8868^{*}$ & -0.011 \\
\hline
\end{tabular}

Note: TS: total soluble solis, AT: antioxidant activity, LC: lycopene, CR: $\beta$-carotene, PP: polyphenol, FL: flavonoid

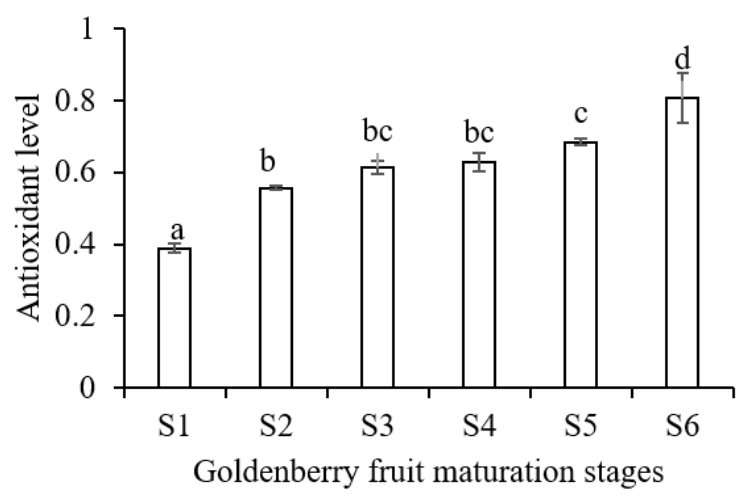

Figure 6. Effect of six different goldenberry maturation stages S1 (green berry covered by fresh green calyx), S2 (greenishyellow berry covered by fresh pale green calyx), S3 (pale yellow berry covered by fresh greenish-yellow calyx), S4 (pale yellow berry covered by fresh pale yellow calyx), S5 (yellow berry covered by semi wilt pale yellow calyx), S6 (orange berry covered by full wilt white calyx) - on antioxidant level (\%). Note: the different alphabet above the rectangular bar is significantly different based on DMRT at $\alpha 5 \%$; the error bar represents the standard deviation

In contrast to polyphenol, the flavonoid content was significantly affected by the fruit maturation stages. There was an improvement of flavonoid content as the goldenberry fruit getting mature. Green berry that is still covered by fresh green calyx had the lowest flavonoid content and it was increased up to more than two-fold when the berry becomes orange ones that covered by full wilt white calyx (Figure 5b). The result of present experiment was in agreement with earlier study by Bhandari and Lee (2016) on tomatoes. The increase of flavonoid concentration was associated with the increasing activity of chalcone synthase as the precursor of flavonoid biosynthesis (Lewinsohn et al. 1989). Aside maturation stage, the flavonoid content of fruit could also be affected by genotype and modification of the growing environment (Ridwan et al. 2021; Omidi et al. 2018; Golkar and Taghizadeh 2018; Pan and Guo 2016).

\section{Correlation between antioxidant activity and metabolites content during fruit maturation}

Present finding highlighted the significant difference in antioxidant activity among several fruit maturation stages (Figure 6). There was an increasing pattern of antioxidant activity as the fruit getting mature. The fruit in S1 stage (green berry covered by fresh green calyx) increased its antioxidant activity up to $107 \%$ when they reached S6 stage (orange berry covered by full wilt white calyx). This finding was similar to Yan et al. (2006) in guava and Chang et al. (2008) in goldenberry. The increase of antioxidants could be explained by the correlation analysis among phytochemicals observed. Pearson correlation analysis showed that all phytochemical variables observed, except polyphenol have a positive and significant antioxidant activity (Table 1). In agreement to present finding, previous studies have been reported the biological activity of lycopene, $\beta$-carotene and polyphenol as antioxidants (Calvindi et al. 2020; Hussain et al. 2019; Goodarzi et al. 2018; Sayahi and Shirali 2017; Setyawan and Darusman 2008; Burda and Oleszek 2001), however, the opposite result was not proved only in term of polyphenol. The correlation results in the present work enriched previous studies that reported a significant correlation among the physical characters of the golden straw (Yildiz et al. 2015).

In conclusion, this work revealed significant improvement of fruit juice $\mathrm{pH}$, TSS, lycopene, $\beta$-carotene, and flavonoid content as the fruit gets mature. The fruit maturation stages showed no significant effect on polyphenol level. The antioxidant activity of goldenberry was positive and significantly correlated by all observed variables, except polyphenol content.

\section{ACKNOWLEDGEMENTS}

The authors would like to thank Waida Farm, Sumedang, Indonesia as the selected goldenberry orchard for preparing plant materials in present work and all laboratory members involved in the metabolite analysis.

\section{REFERENCES}

Arbiastutie Y, Marsono D, Hartati MS, Purwanto R. 2017. The potential of understorey plants from Gunung Gede Pangrango National Park (West Java, Indonesia) as cervix anticancer agents. Biodiversitas 18 (1): 109-115. DOI: 10.13057/biodiv/d180116.

Balaguera-Lopez, Helber E, Martinez CA, Harera A. 2015. Refrigeration affects the post-harvest behaviour of 1methylcyclopropene-treated cape gooseberry (Physalis peruviana 1 .) fruits with the caly. Agron Colomb 33: 356-364. DOI: 10.15446/agron.colomb.v33n3.51896.

Baskan SK, Tutem E, Ozer N, Apak R. 2013. Spectrophotometric and chromatographic assessment of contributions of carotenoids and chlorophylls to the total antioxidant capacities of plant food. J Agric Food Chem 61 (47): 11371-11381. DOI: 10.1021/jf403356h.

Beckles DM. 2012. Factors affecting the postharvest soluble solids and sugar content of tomato (Solanum lycopersicum L.) fruit. Postharvest Biol Technol 63: 129-140. DOI: 10.1016/j.postharvbio.2011.05.016.

Ben-Arie R, Segal N, Guelfat-Reich S. 1984. The maturation and ripening of the 'Wonderful' pomegranate. J Am Soc Hortic Sci 109: 898-902.

Bhandari SR, Lee JG. 2016. Ripening-dependent changes in antioxidants, color attributes, and antioxidant activity of seven tomatoes (Solanum 
lycopersicum L.) cultivars. J Anal Methods Chem 2016: 5498618. DOI $10.1155 / 2016 / 5498618$.

Bravo K, Sepulveda-Ortega S, Lara-Guzman O, Navas-Arboleda AA Osorio E. 2015. Influence of cultivar and ripening time on bioactive compounds and antioxidant properties in cape gooseberry (Physalis peruviana L.). J Sci Food Agric 95 (7): 1562-1569. DOI: $10.1002 / \mathrm{jsfa} .6866$.

Budiarto R, Poerwanto R, Santosa E, Efendi D. 2021. Morphological evaluation and determination keys of 21 citrus genotypes at seedling stage. Biodiversitas 22 (3): 1570-1579. DOI: 10.13057/biodiv/d220364.

Butkhup L, Samappito S. 2011. Changes in physicochemical properties, polyphenol compounds and antiradical activity during development and ripening of maoluang (Antidesma bunius L. Spreng) fruits. J Fruit Ornamen Plant Res 19 (1): 85-99.

Burda S, Oleszek W. 2001. Antioxidant and antiradical activities of flavonoids. J Agr Food Chem 49: 2774-2779. DOI: 10.1021/jf001413m.

Burri BJ. 1997. Beta carotene and human health: A review of current research. Nutr Res 17 (3): 547-580. DOI: 10.1016/S02715317(97)00011-0.

Calvindi J, Syukur M, Nurcholis W. 2020. Investigation of biochemical characters and antioxidant properties of different winged bean (Psophocarpus tetragonolobus) genotypes grown in Indonesia. Biodiversitas 21 (6): 2420-2424. DOI: 10.13057/biodiv/d210612.

Chang JC, Lin CC, Wu SJ, Lin DL, Wang SS, Miaw CL, Ng LT. 2008. Antioxidative and hepatoprotective effects of Physalis peruviana extract against acetaminophen-induced liver injury in rats. Pharm Biol 46: 724-731. DOI: 10.1080/13880200802215768.

Crouch I. 2003. 1-Methylcyclopropene (smartfresh tm) as an alternative to modified atmosphere and controlled atmosphere storage of apples and pears. Acta Hortic 600: 433-436. DOI: 10.17660/ActaHortic.2003.600.64.

Davies J. 2000. Tomatoes and health. J Soc Health 120 (2): 81-82. DOI: 10.1177/146642400012000201

Ersoy N, Bagci Y. 2011. Some physico-chemical properties and antioxidant activities of goldenberry (Physalis peruviana L.), pepino (Solanum muricatum Ait.) and passiflora (Passiflora edulis Sims) tropical fruits. Univ Selcuk J Agric Food Sci 25 (3): 67-72.

Etzbach L, Pfeiffer A, Weber F, Schieber A. 2018. Characterization of carotenoid profiles in goldenberry (Physalis peruviana L.) fruits at various ripening stages and in different plant tissues by HPLC DADAPCI-MSn. Food Chem 245: 508-517. DOI: 10.1016/j.foodchem.2017.10.120.

Fawole OA, Opara UL. 2013. Effects of maturity status on biochemical content, polyphenol composition and antioxidant capacity of pomegranate fruit arils (cv Bhagwa). South Afr J Bot. 85: 23-31. DOI: $10.1016 /$ j.sajb.2012.11.010.

Fredes C, Montenegro G, Zoffoli JP, Gomez M, Robert P. 2012 Polyphenol content and antioxidant activity of maqui (Aristotelia chilensis Molina Stuntz) during fruit development and maturation in Central Chile. Chilean J Agric Res 72 (4): 582-589. DOI: 10.4067/S0718-58392012000400019.

Gil MI, Garcia-Viguera C, Artes F, Tomas- Barberan FA. 1995. Changes in pomegranate juice pigmentation during ripening. J Sci Food Agric 5 (68): 77-81. DOI: $10.1002 /$ jsfa.2740680113

Golkar P, Taghizadeh, 2018. In vitro evaluation of phenolic and osmolyte compounds, ionic content, and antioxidant activity in safflower (Carthamus tinctorius L.) under salinity stress. Plant Cell Tiss Organ Cult 134: 357-368. DOI: 10.1007/s11240-018-1427-4

Goodarzi S, Raflei S, Javadi M, Haghighian HK, Noroozi S. 2018. A review on antioxidants and their health effects. J Nutr Food Security 3 (2): 106-112.

Gutierrez MS, Trinchero GD, Cerri AM, Vilella F, Sozzi GO. 2008 Different responses of goldenberry fruit treated at four maturity stages with the ethylene antagonist 1-methyl cyclopropane. Postharv Bio Tech 48: 199-205. DOI: 10.1016/j.postharvbio.2007.10.003.

Hdider C, Ilahy R, Tlili I, Lenucci MS, Dalessandro G. 2013. Effect of the stage of maturity on the antioxidant content and antioxidant activity of high-pigment tomato cultivars grown in Italy. Food 7: 1-7.

Hussain A, Pu H, Sun DW. 2019. Measurements of lycopene contents in fruit: A review of recent developments in conventional and nove techniques. Crit Rev Food Sci Nutr 59 (5): 758-769. DOI: 10.1080/10408398.2018.1518896.

Ilahy R, Hdide C, Lenucci MS, Tlili I, Dalessandro G. 2011. Antioxidant activity and bioactive compound changes during fruit ripening of high-lycopene tomato cultivars. J Food Compost Anal 24 (4-5): 588595. DOI: $10.1016 /$ j.jfca.2020.11.003.

Islam MK, Khan MZH, Sarkar MAR Absar N, Sarkars SK. 2013. Changes in acidity, tss, and sugar content at different storage periods of the postharvest mango (Mangifera indica L.) influenced by bavistin DF. Intl J Food Sci 2013: 939385. DOI: 10.1155/2013/939385

Januário F, Petro K, Sato, Franca. 2000. Antimycobacterial physalins from Physalis angulate L. (Solanaceae). Phytother Res 16 (5): 445448. DOI: $10.1002 /$ ptr.939.

Joshi K, Joshi I. 2015. Nutritional composition and biological activities of rasbhari: An overview. Int J Rec Sci Res 6 (11): 7508-7512.

Khodadadi S, Nejadsattari T, Naqinezhad A, Ebrahimzadeh M. 2015. Diversity in antioxidant properties and mineral contents of Allium paradoxum in the Hyrcanian forests, Northern Iran. Biodiversitas 16 (2): 281-287. DOI: $10.13057 /$ biodiv/d160224.

Legge A. 1974. Notes on the history, cultivation and uses of Physalis peruviana L. J Royal Hortic Soc 99 (7): 310-314.

Lewinsohn E, Britsch L, Mazrur Y, Gressel J. 1989. Flavone glycoside biosynthesis in citrus. Plant Physiol 91 (4): 1323-1328. DOI: 10.1104/pp.91.4.1323.

Mahmood T, Anwar F, Abbas M, Boyce MC, Saari N. 2012. Compositional variation in sugars and organic acid at different maturity stages in selected small fruits from Pakistan. Intl J Mol Sci 13 (2): 211-215. DOI: 10.3390/ijms13021380.

Mayorga H, Knapp H, Winterhalter P, Duque C. 2001. Glycosidically bound flavor compounds of cape gooseberry (Physalis peruviana L.). J Agr Food Chem 49: 1904-1908. DOI: 10.1021/jf0011743.

Monerruzzaman KM, Hossain ABMS, Sani W, Saifuddin M. 2008. Effect of stages of maturity and ripening conditions on the biochemical characteristics of tomato. Am J Biochem Biotech 4 (4): 336-344. DOI:10.3844/ajbbsp.2008.336.344.

Mubarok SY, Okabe N, Fukuda, Ariizumi T, Ezura H. 2015. Potential use of a weak ethylene receptor mutant Sletr1-2 as breeding material to extend fruit shelf life of tomato. J Agr Food Chem 63: 7995-800. DOI: $10.1021 /$ acs.jafc.5b02742.

Omidi JF, Shoja MH, Sariri R. 2018. Effect of water-deficit stress on secondary metabolites of Melissa officinalis L.: Role of exogenous salicylic acid. Caspian J Environ Sci 16 (2): 121-134.

Ordonez-Santos LE, Ledezma-Realpe DP. 2013. Lycopene concentration and physicochemical properties of tropical fruits. Food Nutr Sci 4: 758-762. DOI: 10.4236/fns.2013.47097.

Ortega-Garcia F, Blanco S, Peinado MA, Peragon J. 2008. Polyphenol oxidase and its relationship with oeurepin concentration in fruits and leaves of olive (Olea europaea) cv. Picual trees during fruit ripening. Tree Phys 28 (1): 45-54. DOI: 10.1093/treephys/28.1.45.

Pan J, Guo B. 2016. Effects of light intensity on the growth, photosynthetic characteristics, and flavonoid content of Epimedium pseudowushanense B.L. Guo. Molecules 21: 1475. DOI: 10.3390/molecules21111475.

Puente LA, Pinto-Muñoz CA, Castro ES, Cortés M. 2011. Physalis peruviana Linnaeus, the multiple properties of a highly functional fruit: A review. Food Res Int 44: 1733-1740. DOI: 10.1016/j.foodres.2010.09.034.

Ramadan MF, Morsel JT. 2003. Oil goldenberry (Physalis peruviana L.). J Agric Food Chem 51: 969-974. DOI: 10.1021/jf020778z.

Ramadan MF, Morsel JT. 2007. Impact of enzymatic treatment on chemical composition, physicochemical properties and radical scavenging activity of goldenberry (Physalis peruviana L.) juice. J Sci Food Agr 87 (3): 452-460. DOI: 10.1002/jsfa.2728.

Ramadan MF, Morsel JT. 2009. Oil extractability from enzymatically treated goldenberry (Physalis peruviana L.) pomace: Range of operational variables. Int J Food Sci Tech 44 (3): 435-444. DOI: 10.1111/j.1365-2621.2006.01511.x

Ridwan, Hamim, Suharsono, Hidayati N, Gunawan I. 2021. Drumstick (Moringa oleifera) variation in biomass and total flavonoid content in $\begin{array}{llll}\text { Indonesia. Biodiversitas } 22 & \text { (1): 491-498. DOI: }\end{array}$ 10.13057/biodiv/d220159

Sadiyah H, Ashari S, Waluyo B, Soegianto A. 2021. Genetic diversity and relationship of husk tomato (Physalis spp.) from East Java Province revealed by SSR markers. Biodiversitas 22 (1): 184-192. DOI: 10.13057/biodiv/d220124.

Sayahi M, Shirali S. 2017. The antidiabetic and antioxidant effects of carotenoids: A review. Asian J Pharm Res Health Care 9 (4): 186191. DOI: $10.18311 /$ ajprhc/2017/7689. 
Serrano M, Guillen F, Martinez-Romero D, Castillo S, Valero D. 2005. Chemical constituents and antioxidant activity of sweet cherries at different ripening stages. J Agric Food Chem 53: 2741-2745. DOI: $10.1021 / \mathrm{jf} 0479160$.

Sharoba MA, Ramadan MF. 2011. Rheological behavior and physicochemical characteristics of goldenberry (Physalis peruviana) juice as affected by enzymatic treatment. J Food Process Pres 35: 201-219. DOI:10.1111/j.1745-4549.2009.00471.x.

Soeksmanto A, Hapsari Y, Simanjuntan P. 2007. Antioxidant content of parts of Mahkota dewa, Phaleria macrocarpa [Scheff] Boerl. Biodiversitas 8 (2): 92-95. DOI: 10.13057/biodiv/d080203.

Setyawan AD, Darusman LK. 2008. Review: Biflavonoid compounds of Selaginella Pal. Beauv. and its benefit. Biodiversitas 9 (1): 64-81. DOI: $10.13507 /$ biodiv/d090115.

Suwanaruang T. 2016. Analyzing lycopene content in fruits. Agr Agric Sci Proc 11: 46-48. DOI: 10.1016/j.aaspro.2016.12.008.

Trinchero GD, Sozzi GO, Cerri AM, Vilella F, Fraschina AA. 1999. Ripening-related changes in ethylene production, respiration rate and cell wall enzyme activity in goldenberry (Physalis peruviana L.), a solanaceous species. Postharv Bio Tech 16: 139-145. DOI: 10.1016/S0925-5214(99)00011-3.

Yan LY, Teng LT, Jhi TJ. 2006. Antioxidant properties of guava fruit: Comparison with some local fruits. J Sunway Acad 3: 9-20.

Yildiz G, Izli N, Unal H, Uylase V. 2015. Physical and chemical characteristics of goldenberry fruit (Physalis peruviana L.). J Food Sci Technol 52 (4): 2320-2327. DOI: 10.1007/s13197-014-1280-3.

Yora M, Syukur M, Sobir. 2018. Characterization of phytochemicals and yield components in various okra (Abelmoschus esculentus) $\begin{array}{lllll}\text { genotypes. } & \text { Biodiversitas } 19 & \text { (6): 2323-2328. DOI: }\end{array}$ $10.13057 / \mathrm{biodiv} / \mathrm{d} 190641$

Yusnawan E. 2016. The diversity of secondary metabolites in Indonesian soybean genotypes. Biodiversitas 17 (2): 704-710. DOI: 10.13057/biodiv/d170245.

Zarei M, Azizi M, Bashir-Sadr Z. 2011. Evaluation of physicochemical characteristics of pomegranate (Punica granatum 1.) fruit during ripening. Fruits 66: 121-129. DOI: 10.1051/fruits/2011021. 